This item was submitted to Loughborough's Research Repository by the author.

Items in Figshare are protected by copyright, with all rights reserved, unless otherwise indicated.

\title{
Tourism destination preferences of low-cost airline users in the East
}

\section{Midlands}

PLEASE CITE THE PUBLISHED VERSION

http://dx.doi.org/10.1016/j.jtrangeo.2009.07.004

PUBLISHER

(C) Elsevier

VERSION

AM (Accepted Manuscript)

LICENCE

CC BY-NC-ND 4.0

\section{REPOSITORY RECORD}

Davison, Lisa, and Tim Ryley. 2019. "Tourism Destination Preferences of Low-cost Airline Users in the East Midlands". figshare. https://hdl.handle.net/2134/11390. 
This item was submitted to Loughborough's Institutional Repository (https://dspace.lboro.ac.uk/) by the author and is made available under the following Creative Commons Licence conditions.

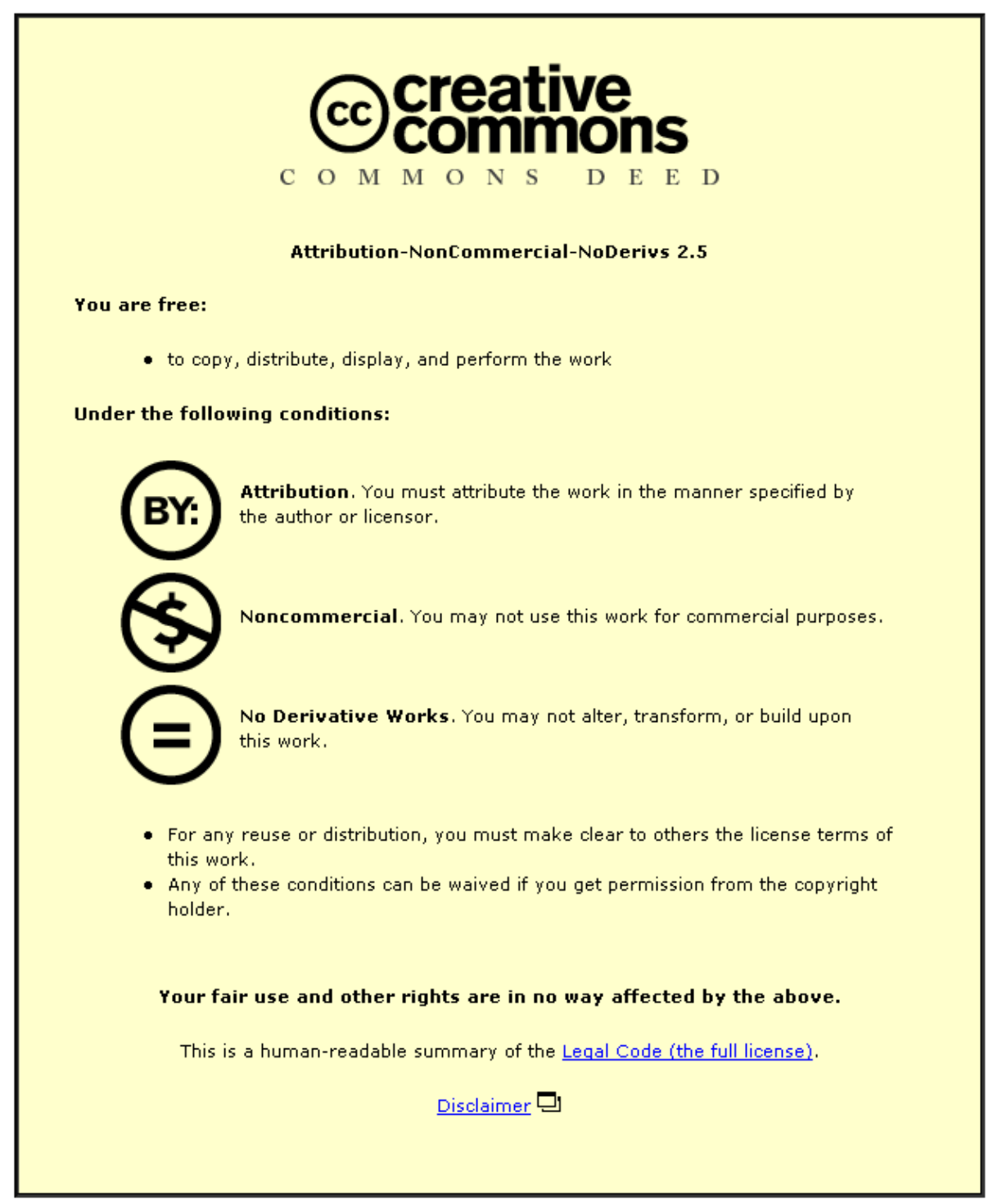

For the full text of this licence, please go to: http://creativecommons.org/licenses/by-nc-nd/2.5/ 
TOURISM DESTINATION PREFERENCES OF LOW-COST AIRLINE USERS IN THE EAST MIDLANDS

\title{
Lisa Davison and Tim Ryley
}

Transport Studies Group, Loughborough University, Leicestershire, LE11 3TU, UK

\begin{abstract}
Increasing demand for air travel, associated with the boom in low-cost airlines, has assisted tourism growth. Expanding opportunities from regional airports underpin an increased propensity to fly. This paper examines European tourism destination preferences and price sensitivity to fly by population segment from an air travel household survey in the East Midlands region of the United Kingdom. Of the eight typical low-cost airline destinations presented to respondents cultural locations such as Rome are preferred. Weekend break leisure trips are particularly attractive to those in employment. Price sensitivity, suggests that increasing financial pressures will have an impact upon growth, however demand for an annual holiday is important, particularly for families.
\end{abstract}

Key words: low-cost airline, tourism, demand 


\section{$1 \quad$ Introduction}

The increasing market presence of low-cost airlines, following the liberalisation of the European market, has provided consumer choice and released a latent demand for air travel. The majority of low-cost airline demand is from leisure travellers (Graham, 2006; Civil Aviation Authority, 2006), although Mason (2005) identifies the increasing number of business travellers who view low-cost airline flights as a good value, flexible option (tickets are transferrable subject to price differential and administration fee), especially on specific routes where frequency is tailored to business demand. The majority of such carriers focus on traffic from regional areas, often surpassing charter carrier activity, which initially increased operation from bases outside London (Civil Aviation Authority, 2005). Despite the high proportion of leisure travellers using lowcost airlines, the business model is suited to attraction-based destinations, with some influx into resort based destinations in terms of second homes, as opposed to the traditional 'tourism-orientated’ niche favoured by charter airlines (Bieger and Wittmer, 2006). This is due to the bilateral links between a tourist destination strategy and air travel business models that drive demand by market segment. Thus, low-cost airlines have been "instrumental” in the development of city, short break destinations, thereby encouraging 'cultural tourism’ (Graham and Shaw, 2008).

Tourism is recognised as being distinct from travel, yet travel is one of its component activities. Air travel in particular, whilst not making up the greatest proportion of tourist journeys in Europe, accounts for a significant share of the distance travelled. Peeters et al. (2007) estimate that the external cost of intra-European tourist air travel 
exceeds $€ 40,000$ million for all citizens in the EU-25, based on 2004 figures; much of this is a result of greenhouse gas emissions having a greater impact on air quality and noise than other modes. In comparison, tourist car travel accounts for just over $€ 15,000$ million. Given that the Davos Declaration (United Nations World Tourism Organisation, 2007) commits the tourist industry to, “mitigate greenhouse gas emissions, derived especially from transport and accommodation activities”, and to encourage consumers to consider their, “climate, economic societal and environmental impact of their options", awareness of air travel choices and the influence of changes in airfare is pertinent.

Distinct from mainland Europe, international tourism to and from the United Kingdom, relies heavily on air travel. There is a proven market for low-cost airlines, demonstrated by a mature level of provision; in 2005, the United Kingdom received over $45 \%$ of all scheduled low-cost airline seats provided on domestic and intra-EU routes (Mason and Alamdari, 2007). Across the market, air travel has increased fivefold over the past 30 years, and demand is projected to be between 2x and 3x current levels by 2030 (Department for Transport, 2003). Though United Kingdom policy encourages efficient use of existing facilities (Department for Transport, 2007), there are planned provisions in the form of terminal and runway expansions, accepting a progressive increase in demand to fly.

The objective of this paper is to examine the demand for low-cost air travel from the East Midlands, concentrating on leisure travel to a range of European tourist destinations. The East Midlands focus reflects regional trends across the United 
Kingdom, thus findings are broadly transferrable to other areas served by regional airports. Segments are identified based on tourist destination preference, these are explored in terms of air travel population segments, propensity to fly, price sensitivity and related socio-demographic attributes.

Findings allow the aviation industry to respond to market schedule and pricing demands for regional airports, and tourist destinations to market themselves to an identified cohort of people. They are of interest more widely, as they provide an indication of price thresholds according to destination preference and market segment.

\section{Destination preferences and holiday trends from the United Kingdom}

The International Passenger Survey 2006 (Office for National Statistics, 2008) shows that United Kingdom residents made 69.5 million visits abroad, $65 \%$ of which were specifically for holiday purposes, plus $17 \%$ to visit friends and relatives; of the total number of visits $81 \%$ utilised air travel. This is in contrast to 32.7 million visits to the United Kingdom, 75\% of which utilised air travel. Of the destinations visited, Europe features heavily, accounting for 79\% of all journeys, though since 2002 the long haul market has grown at a faster rate than short haul. The Civil Aviation Authority (2007) data in Table 1 demonstrates that Spain and the Irish Republic were the most popular air travel destinations during 2007; the destinations of Poland and the Czech Republic experienced the greatest growth between 1997 and 2007.

Table 1. European Union passenger traffic to and from United Kingdom reporting airports (in thousands) by country, 1997 and 2007 and percentage change 
While the number of leisure trips has increased, the length of stay in the European market has fallen (Office of National Statistics, 2008; Mintel, 2008; Mason and Alamdari, 2007). The International Passenger Survey (Office of National Statistics, 2008) demonstrates that while the average length of United Kingdom visit abroad has remained stable, there has been a growth in the proportion of trips classified as: 1-3 nights, or 4-13 nights, with a corresponding drop in trips with no overnight stay and of 14-27 nights. A Mintel report (2008) states that short breaks (involving 1-3 nights away) have been the "main driver” to growth in overall holidays, however, there are also concerns about the effect of recent economic pressures on leisure travel, growth in the number of short breaks taken has slowed to $3 \%$ annual growth in 2007 , down from a high of $9 \%$ in the middle of the decade. However, this decreased level of growth could arguably be apportioned to market saturation and annual leave availability (Graham, 2000).

\section{$3 \quad$ Market segmentation}

Both the aviation and tourism industries acknowledge that there are market segments behaving differently in response to pricing and commodity changes. In aviation this is typically split into business (further split into 'routine' and 'urgent') and leisure (further split into ‘holidays' and 'visiting friends and relations') passengers (Doganis, 2002). Typically, business travel is less price elastic than leisure travel. The low-cost airline business model encourages the booking of outward and return journeys separately (resulting in favourable airfare availability for return flights without a Saturday 
overnight stay), making it difficult for airlines to distinguish price according to market segment willingness to pay. Additionally population segments can be linked to life stage and life cycle events, such as having children or retiring from employment.

Further segments can be identified using cluster analysis, a non-parametric data analysis method, which identifies similarities and differences between individuals. Examples which involve air travel choices include segments detailing the ability and willingness to reduce carbon footprints, through modifications in behaviour (Department for the Environment, Food and Rural Affairs, 2008); and segments examining responsiveness to different policy interventions (Ipsos MORI, 2007), with segments based on sociodemographic and air travel behaviour. Other literature classifies segments according to household characteristics, such as income and socio-economic group, plus other influencing factors such as number of people in travel group. In terms of income levels, figures demonstrate that low-cost airlines have encouraged middle income groups to travel more frequently, while individuals in the lower income groups are making up a smaller proportion of passengers. This finding is from comparison of 1996 and 2005 data, using trips from the primary London airports (Civil Aviation Authority, 2006).

In terms of tourism, Mintel (2008) report that the key market segment contributing to the growth in short breaks are: highly educated, high income households in $\mathrm{AB}$ professions. This market segments is identified as 'DIYers' who investigate and book holidays online, relating directly to the online booking consumer culture, exploited by European low-cost airlines from the outset. Furthermore, low-cost airlines test the 
feasibility of new markets; this perpetuates flexible trip lengths to novel destinations, suiting the 'DIYers' approach to short breaks.

\section{$4 \quad$ Research design}

The household survey, upon which this paper is based, was conducted in Autumn 2007 (boosted in Spring 2008). It had the aim of examining individual responses to low-cost air travel in the East Midlands region of the United Kingdom, for both flyers and nonflyers. It is part of 'Propensity to Fly', a 30-month project funded by the Engineering and Physical Sciences Research Council, to develop stated choice models and improve understanding of segment response to low-cost air travel. The survey questionnaire examines: respondent air travel experience; experience from their nearest regional airport, served by low-cost carriers; future air travel choices; attitudes to air travel; and household characteristics.

This paper focuses on three parts of the household survey: demand for the eight European destinations regularly served by low-cost airlines in the East Midlands, likelihood to book a low cost flight to this destination, and price sensitivity of respondents according to increases and decreases in total return fare for a short haul flight.

Data collection for the East Midlands air travel survey used postal questionnaires, a low cost method that does not involve high personnel or travel costs. That said, there can be difficulties with postal questionnaire surveys in obtaining a representative sample due to 
low response rates. A self-completion questionnaire was posted out to each household sampled, together with a pre-paid return envelope. The request was for one adult within the household to complete the questionnaire and return it in the envelope provided.

Survey design was informed by the Charnwood air travel household survey, conducted in October 2006 (Ryley and Davison, 2008a). In addition, a pilot postal survey with 67 household responses was conducted in August 2007, sampling the towns of Barrowupon-Soar and Woodhouse Eaves within the Charnwood Borough Council area. The survey questionnaire contains a vast array of variables relating to air travel attitudes and behaviour, together with background socio-economic and transport information. The Charnwood air travel survey with 361 responses, across two sample sub areas in the Leicestershire borough of Charnwood will be used, where appropriate, as a comparison and to validate results. However, it should be noted that the two surveys are not repeat samples.

The sampling frame for the survey was the Electoral Register, the record of everyone living within the Council area eligible to vote. The edited version of the Electoral Register was obtained from each of the given Local Authorities. The edited Electoral Register does not include individuals who requested removal of their names from the version given to outside organisations, an option which has been available since 2002. The 2005 Electoral Register included approximately 70\% of those on the full register; a proportion which has reduced annually since 2002 (Information Commissioners Office, 2006). 
The sampling strategy for the survey involved a combination of clustered and random sampling, to develop distinct spatial population groups. A quota was set for sampling both the local authority and sub-areas. The criteria for the local authority was to sample at a range of distances from East Midlands airport, the most central airport in the region; to get a mixture of urban and rural districts (at least one of each, where Nottingham, Leicester, Derby, Northampton and Lincoln were classed as urban districts within the East Midlands); and not to select adjacent authorities. The five sampled local authorities were: Hinckley \& Bosworth, Newark \& Sherwood, Northampton, North East Derbyshire, and Nottingham. Two sub-areas were selected from each local authority, to include a range of different socio-economic characteristics, reflecting England and Wales (given the lack of East Midlands data) (Office for National Statistics, 2004); again adjacent areas were rejected. Figure 1 illustrates the position of these five sampled local authorities and the Charnwood Borough Council area, in relation to East Midlands, Birmingham International and Luton airports.

\section{Figure 1: Survey sample sites in relation to East Midlands, Birmingham International and Luton Airports (Note: Figure not included in this version)}

\section{$5 \quad$ Survey sample}

Of the 5,000 questionnaires posted out across the East Midlands in Autumn 2007, 517 usable questionnaires were returned initially. This represents an overall response rate of $10 \%$; lower than expected (postal survey questionnaires tend to have response rates of between $10 \%$ and $25 \%$ ). Table 2 shows the response by sub-area for each survey, together with multiple deprivation level by quintile (quintile 1 equates to being in the 
most deprived $20 \%$ of super output areas, through to 5 the least deprived $20 \%$ ). It shows that, as expected, there are lower response rates in areas with higher levels of deprivation. Interest in an air travel survey is likely to be highest amongst people who fly, which will have a bearing upon response from areas of high multiple deprivation. For instance, the two sub-areas with the highest deprivation levels (quintile 1) have the lowest response rates (both 6\%). To minimise the bias of low response by sub-area, further questionnaires were sent to those with less than 50 responses. This boost considered existing response rate and number of surveys required to reach 50 in each. In total, 1,300 further surveys were posted during Spring 2008. Of these, 88 (7\% response rate for the boost) were returned, resulting in 605 overall returns (10\% response rate). Response rate remains lowest in the areas with higher deprivation.

\section{Table 2. Response rates by area and deprivation level, East Midlands survey sample}

Within the sample, there is a relatively even split by age; by gender the sample has a higher proportion of females (63\%). The most frequent 'current status' categories amongst respondents are employed full-time (36\%) and permanently retired from work (29\%). Of the households in the sample, 32\% contain children. The Charnwood sample also had a greater proportion of female respondents (57\%) and the same proportion of households contain children (32\%). Again the most frequent current status are employed full time and permanently retired, however, a higher proportion within the Charnwood sample are in employment (45\%) and a lower proportion permanently retired (20\%). 
Leisure travel dominates the East Midlands air travel survey response, with 64\% of the sample making at least one return flight for leisure purposes during the previous year. However, a segment of 50 (8\%) travelled at least once for business purposes during the previous year. Furthermore, a non-flying segment (not having flown in the previous year) of 129 (21\%) and a frequent flyer segment (flying 4+ times in the previous year) of 97 (16\%), are identified. Table 3 illustrates the high proportion of respondents from each sample area who have used their nearest airport across a range of time scales. Results demonstrate the high demand for flights from regional airports.

\section{Table 3: Use of nearest airport by local authority area}

The air travel survey included statements referring to individual holiday preferences. Results demonstrate an environmentally conscious segment of 40 respondents (8\%), who are trying to fly less for environmental reasons, and a security concerned segment of 48 (9\%), who are discouraged from flying because of changes security.

Hierarchical cluster analysis was applied to the results of the East Midlands survey respondents, to develop air travel population segments according to categorical air travel behaviour and household characteristics (for further methodological details see Ryley and Davison, 2008b). Ward's method was used for the final cluster solutions because it minimises within group variation, therefore resulting in clusters of a similar size. Variables informing the cluster analysis were air travel behaviour (frequency of flying and purpose of trip) and household / individual characteristics (gender, age, children in household, status, personal income and multiple deprivation quintile of sub- 
area), thus incorporating the effect of life stage into the segments. From the 418 individuals who had responded to each variable included, seven segments were identified $^{1}$. These are the segments, applied to the analysis in this paper:

- Retired annual holiday makers

- Less mobile, low earners

- Working women who take annual holiday 75 (19\%)

- Employed frequent flyer

- Family orientated, female, holiday makers

- High income, frequent flyers

- Retired frequent flyers
$99(25 \%)$

$78(20 \%)$

$73(18 \%)$

$37(9 \%)$

$20(5 \%)$

$14(4 \%)$

The air travel population segments include a small segment of 14 individuals to differentiate between retired frequent flyers and retired annual holiday makers.

Pearson's chi-square was used to test the Null hypothesis of independence between the segments based on destination preference with these air travel population segments and other questionnaire variables, such as household with children and price sensitivity. Chi-square tests are suited to categorical and nominal data; calculations are based upon the difference in observed and expected frequencies, with similar values for each indicating independence. The test determines whether the observed frequencies are significantly different from the expected frequencies; critical values mean the level of statistical significance can be assessed, indicating the likelihood they occurred by

\footnotetext{
${ }^{1}$ A further, small cluster of 22 respondents whose status was classed as 'other' was excluded due to this being the influencing variable
} 
chance (Urdan, 2005). Statistically significant relationships are considered in this analysis at the $90 \%, 95 \%$ and $99 \%$ confidence levels.

\section{Segmentation based on European tourism destination preferences}

\subsection{European tourism destination preference in context}

The survey examined respondent holiday preference for a range of eight typical lowcost airline destinations: Edinburgh, Dublin, Prague, Rome, Berlin, Alicante, Malaga and Faro, mapped in Figure 2. To put the question into context, Table 4 demonstrates the popularity of the destination by existing passenger numbers and service provision. In this case it does not distinguish between business and leisure travellers. Of the routes, Dublin has the greatest traffic and Berlin the smallest. Between 2006 and 2007, Faro and Rome experienced the greatest market growth.

Figure 2: Position of eight European tourism destinations, served by low cost airline (Note: Figure not included in this version)

Table 4. Passenger numbers and route provision from the United Kingdom to eight European, low cost airline destinations, 2007

Of the destinations, Faro, Alicante and Malaga are 'summer sun destinations' with a distinct leisure role. Charter provision is higher and the majority of passengers flew from the United Kingdom regions. Other destinations, such as Berlin, Edinburgh and Rome, as capital cities, maintain greater core connectivity with a high share of 
passengers travelling from the more constrained London airports, and a much lower proportion of charter services. Berlin in particular, has a defined business role, with a similar number of routes from the London airports as regional airports. Edinburgh shares this business connectivity with a $50 \%$ of routes being from London. However, geographically Edinburgh is also accessible by surface travel alternatives from London and other British regions. When compared to Berlin and Edinburgh, Rome receives a greater proportion of flights from regional airports, reflecting a strong leisure demand. Dublin and Prague share similar characteristics, except for the much higher volume of traffic into Dublin. They have a low proportion of charter services but around half of their services are from regional airports. While low-cost airlines operate on all these routes, these characteristics suggest that they are most dominant on the Dublin and Prague routes. Two of the destination, Berlin and Rome, can be classed as multi-airport cities, serviced by three (Tegel, Schonefield and Templehof) and two airports (Fiumicino and Ciampino) respectively. Of these, the two most dominant low-cost airline services from the United Kingdom operate to Schonefield and Ciampino.

\subsection{Tourism destination preference segment background and definition}

Respondents ranked the destinations in the order that they would like to visit them. Rome is by far the most popular (first choice for $42 \%$ of respondents), mainly because of the historical sights and culture, for example "Italy, favourite destination for holiday, Rome fantastic city for culture and history”. This is similar to the reasons for Prague, the second choice destination. Both are key markets for low-cost airlines. 
The reasons for all destinations relate to experience from previous visits, and a desire to visit somewhere they have never been (but would like to see). The Charnwood sample ranked Rome, Prague and Faro as the top three destinations from the choice of eight, the same as the East Midlands sample.

There is a statistically significant relationship between whether an individual has visited a destination and preferred destinations (Chi-square test at 99\% level, except visitors to Edinburgh at 95\% level and Rome at 90\% level). For the summer sun destinations of Alicante, Malaga and Faro, this is a positive relationship; people prefer to make return visits to destinations they have been too. In the case of Alicante and Malaga, visitors also favour the other summer sun destinations, whereas visitors to Faro do not. For the city destinations of Rome, Prague, and Edinburgh individuals are least likely to prefer summer sun destinations but may favour a different city destination than the one visited previously. This reiterates the fact that the segment who take city breaks like the novelty of trying new destinations. People, who have visited Edinburgh, are more likely to favour Prague and Berlin, visitors to Prague favour Berlin and visitors to Rome, Prague. This is not to say these destinations do not attract repeat visitors, it is just they attract a similar proportion of first time visitors. Exceptions to these cities are Berlin and Dublin, where there are higher proportions of return visitors. Furthermore, visitors to Edinburgh and Dublin often favour mainland Europe destinations, whereas the reverse is not true.

Respondents were asked whether they would like to visit their preferred destination for a weekend or a week. Prague and Berlin are preferred as weekend destinations (72\% 
and 73\% respectively - weekend), whereas, Faro, Malaga and Alicante are week-long holiday destinations (95\%, 95\% and 83\% respectively - week-long). The remaining destinations are split between weekend break and week-long holiday. This varies slightly for the Charnwood survey. In addition to Prague, Edinburgh and Dublin are seen as weekend break destinations and Berlin is viewed as similar to Rome, suitable for both short breaks and week-long holidays. There is a statistically significant relationship between destination and trip length for both the East Midlands and Charnwood surveys (Chi-square test at 99\% level).

By combining the most popular destinations with preferred length of trip, tourism destination preference segments can be defined, accounting for $66 \%$ of the sample population. These are:

- Summer sun destination for a week (21\%);

- Rome for a weekend (19\%);

- Rome for a week (18\%) and

- Prague for a weekend (8\%).

\section{$7 \quad$ Tourism destination preference segment characteristics}

To further understand the demands of tourism destination preferences of low-cost airline users in the East Midlands, identified segments were examined in terms of air travel population segment, propensity to fly and price sensitivity. Results are summarised in Table 5. 


\section{Table 5. Summary of tourism destination preference segment characteristics}

\subsection{Air travel population segments}

Of the air travel population segments, the 'employed frequent flyers' favour weekend breaks to either Rome or Prague, the 'family orientated, female holiday makers' favour Rome for the weekend, 'retired annual holiday makers' prefer Rome for a week and the 'high income frequent flyers', and 'retired frequent flyers' choose summer sun, weeklong holidays. There is a statistically significant relationship between the destination preference segments and the air travel population segments (Chi-square test at 99\% level). This is reflected in the statistically significant relationship between destination preference segment and income, employment status (e.g. respondents with in employment with an income of $£ 10,000$ or more prefer weekend breaks to week-long holidays), and age (e.g. older respondents preferring the week-long options). For income and employment status this is significant at the $99 \%$ level and for age at the 95\% level. Gender has no significant impact on destination choice.

Reasons for the preferences of the 'employed' segments could relate to time availability of employed respondents, or that they view European destinations as supplementary to a lengthier, longer haul holiday. Classifying previous flight destination as 'Britain and Ireland' (including the Channel Islands), 'European destinations' (including all other destinations in the lowest band of United Kingdom government air passenger duty APD) and 'destinations outside Europe' (remaining countries), there is no statistically significant relationship between this and air travel population segments. However, there 
is a statistically significant relationship (Chi-square at 99\% confidence level) between employment (full time employed or not) and previous flight destination. Those classed as employed full time are significantly more likely to have flown within Britain and Ireland, and to a non-European destination. The latter suggests that a break in Europe is a second holiday for a greater proportion of employed respondents.

\subsection{Group size and propensity to book a low cost flight}

Respondents were also asked how many people they would like to travel with. There is a statistically significant relationship between the response and the destination preference segment (Chi-square at 99\% level). The summer sun destinations are popular for groups of three or four people in particular, indicative of the destinations role with families and groups of friends. The city destinations are popular for couples or two people travelling together. Prague is also slightly more popular for groups of 5 plus; further analysis of the qualitative data suggests that this is a result of the popularity with 'stag and hen parties’.

Also of interest is the likelihood that respondents will take a low cost flight to their first choice destination. The return flights offered in the experiment were priced between $£ 39$ and $£ 60$. Respondents were asked the likelihood of booking a return flight, at these rates, to their first choice destination (for either a week-long holiday or a weekend break), if they had the opportunity over the next 12 months. Given this, of the respondents, $13 \%$ would definitely book a flight and a further $52 \%$ state it is likely that they would. There is a significant relationship between tourism destination preference 
segment and propensity to fly (Chi-square at 99\% level). Respondents preferring a weekend break to Prague are most likely to book overall, whereas those choosing a week long holiday at a summer sun destination are most likely to 'definitely’ book a flight. Conversely, respondents favouring Rome for a weekend break are least likely to book a low cost flight over the coming 12 months.

Of the other socio-demographic, economic and behavioural factors considered in this paper, only the number flights (total and leisure) have a statistically significant impact on the likelihood to book. A general trend is that the more frequently a person travelled during the previous 12 months, the more likely they are to book a low cost flight to their preferred destination in the next 12 months. This relationship is particularly clear when cross-tabulated with the number of leisure flights taken. Of those unlikely to book one of these flights, reasons relate to not being able to afford the trip, to having a holiday already planned for next year (e.g. "I am planning on going back to the Maldives so would not be able to afford a second holiday”), and the effect of children reducing air travel opportunities (e.g., "I have two small children, and as a full time mum don't bring in a salary. I don't want to be confined to plane / airport with two small children”).

\subsection{Price sensitivity}

Respondents were asked how their air travel choices might change in the future, in response to changes in the costs associated with air travel. They stated whether they would "probably fly more often”, have "no change in air travel” or "probably fly less often” for various changes in air fares (return flights). The proposed price level 
reductions are by $£ 20$ and $£ 10$ for all return flights; the proposed price rises are by $£ 10$, $£ 20, £ 50$ and $£ 100$ for all return flights. The prices relate to total air fares, low cost or otherwise, including taxes.

Analysis was undertaken for the 392 respondents who had flown the previous year and answered for each air fare presented. Table 6 shows the results. A price rise of $£ 50$ for all return flights is the increase that ensures most respondents would "probably fly less often” (244, 63\%). A group of respondents (108, 28\%) would not change their air travel even if air fares rose by $£ 100$ for all return flights. A statistically significant relationship exists between the number of flights taken in the previous year and this group (Chi-square test at 95\% level). A high proportion of respondents who made one (35\%) or two (32\%) return journeys in the previous year would make "no change in air travel” in response to an increase of $£ 100$, demonstrating relatively inelastic demand for one or two annual holidays. However, $24 \%$ of respondents who made five or more trips in the previous 12 months would not change their flight frequency.

Table 6. Responses to price sensitivity statements from the East Midlands survey sample

There is also evidence of suppressed demand for air travel amongst some respondents. Of the 392 respondents, 133 (34\%) would "probably fly more often” at a reduction in return air fares by $£ 20$. When compared to the results for Charnwood air travel survey 2006 (Ryley and Davison, 2008a), the East Midlands sample is slightly less price sensitive. More respondents in the Charnwood survey would fly less frequently with an increase of $£ 50$ (65\%) and fly more frequently with a reduction of $£ 20$ (39\%). This may 
reflect the response to Air Passenger Duty increases in February 2007, suggesting that travellers realise they are willing to absorb air fare increases.

Chi-square tests did not demonstrate a statistically significance relationship between tourism destination preference segments and price sensitivity. However, there was an elevated suppressed demand at airfare reductions of $£ 20$ and $£ 10$ for respondents favouring Alicante, and the reverse was true for those preferring Berlin (Chi-square at 90\%). Furthermore, the seven air travel population segments have different levels of price sensitivity. The 'family orientated, female holiday makers' segment has the highest suppressed demand, 43\% would probably fly more if flight prices reduced by $£ 20$. This is reflected at a statistically significant level (Chi-square at $90 \%$ level) for households with children, which are more receptive to reductions of $£ 10$ and $£ 20$. This is to be expected given the extra costs of travelling as a family. However, there is no statistically significant relationship between having children in the household, and flying less in response to price increases, relating to the high proportion of families who enjoy a single annual holiday. As expected, at lower levels of price increase (£10, £20 and £50) 'Less mobile, low earners’ are most sensitive to change; higher proportions of this population segment would probably fly less often as a result (13\%, 25\% and 69\% respectively).

\section{$8 \quad$ Discussion and conclusions}

Data from the East Midlands air travel survey shows a high tourist demand for low cost flights from regional airports. There is a greater desire for cultural tourism-based 
destinations, illustrated by the popularity of Rome and Prague and evidence of a desire to trade between European city destinations. To maintain consumer interest, airlines need to continue to innovate, providing tourism destinations which meet these requirements.

Whilst cultural cities such as Prague and Berlin attract weekend break-takers, and the summer sun destination such as Alicante and Faro attract week-long holiday makers, Rome has the capability to suit both markets. These findings have direct implications for the aviation industry in terms of route scheduling and customer demands upon airport facilities. European tourist organisations and airports will benefit from the knowledge that 'employed' segments usually favour weekend breaks, whilst the 'retired' and 'family orientated female' segments opt for a week-long holiday. In terms of responding to group size, cultural cities are predominantly couple focused, whereas the summer sun destinations attract groups of holiday makers.

In terms of policy and market-based impacts, financial penalties provide a more effective disincentive to fly. The majority of respondents are sensitive to price increases. A $£ 50$ rise in total air fare for a short haul flight is identified as the level at which most people (62\%) would stop flying as frequently, whereas only $8 \%$ of respondents are trying to reduce the number of flights taken for environmental reasons. Despite the evident price sensitive nature of the low-cost airline market, the demand for an annual holiday appears relatively inelastic. This is particularly the case for families; whilst families are most receptive to decreases in price, demonstrating the collective 
cost of travelling with children, they are not so receptive to price increases. This demonstrates indirect support for a policy which does not penalise an annual holiday.

Related to price sensitivity, recent pressures on household disposable income, (see Mintel, 2008), will force many individuals to re-evaluate their leisure travel using lowcost airlines. This will have a particular impact upon middle income group, as identified by the Civil Aviation Authority (2006). The resultant route reduction will limit choice for travellers, exerting a cumulative impact upon passenger numbers.

\section{Acknowledgements}

The authors would like to acknowledge the Engineering and Physical Sciences Research Council who have funded the Propensity to Fly project. They would also like to thank Dr Janet Dickinson and Dr Stewart Barr, who chaired the Tourism and Climate Change sessions at the Royal Geographical Society Annual Conference, London, August 2008. An earlier version of this paper was presented at one of these sessions. The authors are grateful to the two anonymous referees for their constructive feedback.

\section{References}

Bieger, T., and Wittmer, A., 2006. Air transport and tourism — perspectives and challenges for destinations, airlines and governments. Journal of Air Transport Management, 12(1), 40-46. 
Civil Aviation Authority, 2007. United Kingdom airports annual statistics.

[http://www.caa.co.uk/default.aspx?catid=80\&pagetype=88\&sglid=3\&fld=2007Annual, accessed 09-07-2009]

Civil Aviation Authority, 2006. No-frills carriers: revolution or evolution? Civil Aviation Authority Report CAP 770.

Civil Aviation Authority, 2005. United Kingdom regional air services. Civil Aviation Authority Report CAP 754.

Department for Environment, Food and Rural Affairs, 2008. A framework for environmental behaviours: a report. HMSO, London.

Department for Transport, 2003. The future of air transport. Air Transport White Paper. HMSO, London.

Department for Transport, 2007. The future of air transport. Progress Report. HMSO, London.

Doganis, R., 2002. Flying off course: the economics of international airlines, Third edition. Routledge, London.

Graham, A., 2000. Demand for leisure air travel and limits to growth Journal of Air Transport Management 6: 109-118 
Graham, A., 2006. Have the major forces driving leisure airline traffic changed? Journal of Air Transport Management, 12(1), 14-20.

Graham, B., and Shaw, J., 2008. Low-cost airlines in Europe: reconciling liberalization and sustainability. Geoforum 39(3), 1439-1451.

Ipsos MORI, 2007. Attitudes to aviation and climate change. Research study conducted for the Commission for Integrated Transport.

[http://www.cfit.gov.uk/docs/2007/climatechange/pdf/2007climatechange-survey.pdf accessed 09-07-2009]

Information Commissioners Office, 2006. Data Protection Act 1998: supervisory powers of the Information Commissioner, Enforcement Notice.

[http://www.ico.gov.uk/upload/documents/library/corporate/notices/b4u_enforcement_n otice_130706.pdf, accessed 09-07-2009]

Mason, K.J., 2005. Observations of fundamental changes in the demand for aviation services. Journal of Air Transport Management 11(1), 19-25.

Mason K. J., and Alamdari, F., 2007. EU network carriers, low cost carriers and consumer behaviour: a Delphi study of future trends. Journal of Air Transport Management, 13(5), 299-310. 
Mintel, 2008. Short breaks abroad, United Kingdom, May 2008

[http://academic.mintel.com/sinatra/oxygen_academic/search_results/show\&/display/id $\underline{=280390}$, accessed 09-07-2009]

Office of National Statistics, 2008. Travel Trends 2006. HMSO: London

Office for National Statistics, 2004. Neighbourhood Statistics.

[http://www.neighbourhood.statistics.gov.uk/dissemination/, accessed 09-07-2009]

Peeters, P., Szimba, E., and Duijnisveld, M., 2007. Major environmental impacts of European tourist transport. Journal of Transport Geography, 15(2), 83-93.

Ryley, T.J., and Davison, L.J., 2008a. United Kingdom air travel preferences: evidence from an East Midlands household survey. Journal of Air Transport Management, 14(1) 43-46.

Ryley, T.J., and Davison, L.J., 2008b. Air travel preferences by population segment: results from a United Kingdom household survey. Presented at the Air Transport Research Society $12^{\text {th }}$ World Conference, Athens, 6-10 July, 2008.

United Nations World Tourism Organisation, 2007. Davos Declaration: climate change and tourism, responding to global challenges. Second International Conference on Climate Change and Tourism, Davos, Switzerland, 3 October 2007 [http://www.worldtourism.org/pdf/pr071046.pdf, accessed 09-07-2009] 
Urdan, T., 2005. Statistics in plain English. Laurence Erlbaum A Associates: Mahwah 
Table 1. European Union passenger traffic to and from United Kingdom reporting airports (in thousands) by country, 1997 and 2007 and percentage change

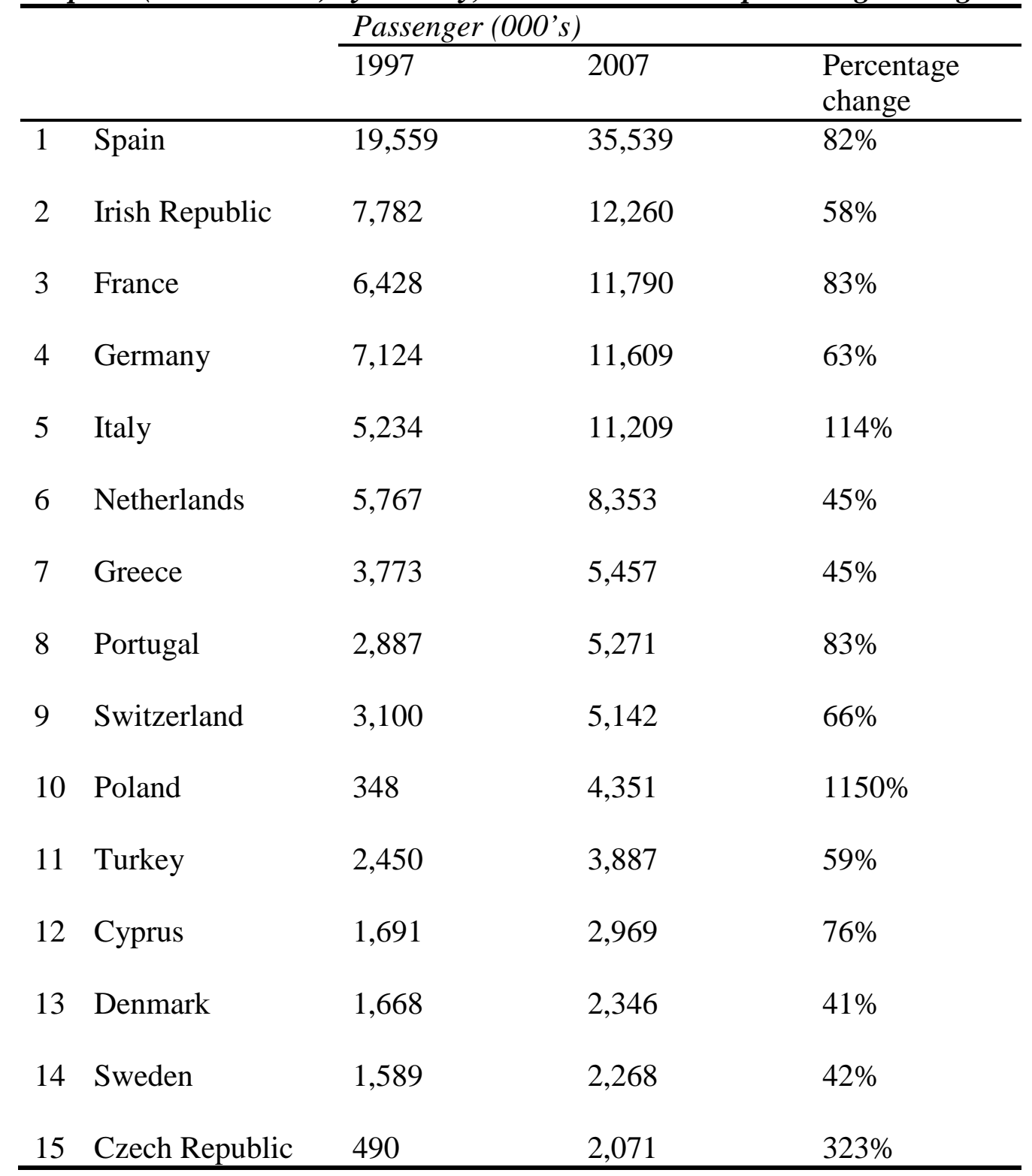

Source: Civil Aviation Authority, 2007 
Table 2. Response rates by area and deprivation level, East Midlands survey sample

\begin{tabular}{|c|c|c|c|c|c|c|c|}
\hline $\begin{array}{l}\text { Area } \\
\text { (Electoral } \\
\text { Register) }\end{array}$ & $\begin{array}{l}\text { Sub-area } \\
\text { (main } \\
\text { Ward } \\
\text { area) }\end{array}$ & $\begin{array}{l}\text { Multiple } \\
\text { deprivation* }\end{array}$ & $\begin{array}{l}\text { Initial } \\
\text { sample } \\
\text { size }\end{array}$ & $\begin{array}{l}\text { Responses } \\
\text { received } \\
\text { initial } \\
\text { survey }\end{array}$ & $\begin{array}{l}\text { Boost } \\
\text { sample } \\
\text { size }\end{array}$ & $\begin{array}{l}\text { Responses } \\
\text { received } \\
\text { boost }\end{array}$ & $\begin{array}{l}\text { Total number } \\
\text { of } \\
\text { questionnaires } \\
\text { received }\end{array}$ \\
\hline Northampton & $\begin{array}{l}\text { St } \\
\text { David's }\end{array}$ & Quintile 1 & 500 & $31(6 \%)$ & 450 & $15(3 \%)$ & $46(5 \%)$ \\
\hline Northampton & $\begin{array}{l}\text { Nene } \\
\text { Valley }\end{array}$ & Quintile 4 & 500 & 59 (12\%) & - & - & 59 (12\%) \\
\hline $\begin{array}{l}\text { North East } \\
\text { Derbyshire }\end{array}$ & Tupton & Quintile 2 & 500 & 49 (10\%) & 100 & 15 (15\%) & 64 (11\%) \\
\hline $\begin{array}{l}\text { North East } \\
\text { Derbyshire }\end{array}$ & Eckington & Quintile 5 & 500 & 63 (13\%) & - & - & 63 (13\%) \\
\hline $\begin{array}{l}\text { Hinckley and } \\
\text { Bosworth }\end{array}$ & Barwell & Quintile 3 & 500 & 48 (10\%) & 100 & 12 (12\%) & 60 (10\%) \\
\hline $\begin{array}{l}\text { Hinckley and } \\
\text { Bosworth }\end{array}$ & Clarendon & Quintile 5 & 500 & 46 (9\%) & 100 & 15 (15\%) & $61(10 \%)$ \\
\hline $\begin{array}{l}\text { Newark and } \\
\text { Sherwood }\end{array}$ & Boughton & Quintile 1 & 500 & $29(6 \%)$ & 450 & $21(5 \%)$ & $50(5 \%)$ \\
\hline $\begin{array}{l}\text { Newark and } \\
\text { Sherwood }\end{array}$ & Lowdam & Quintile 4 & 500 & 80 (16\%) & - & - & 80 (16\%) \\
\hline Nottingham & $\begin{array}{l}\text { Leen } \\
\text { Valley }\end{array}$ & Quintile 2 & 500 & 48 (10\%) & 100 & $10(10 \%)$ & 58 (10\%) \\
\hline Nottingham & $\begin{array}{l}\text { Bulwell } \\
\text { Forest }\end{array}$ & Quintile 3 & 500 & $64(13 \%)$ & - & - & 64 (13\%) \\
\hline Total & & & 5,000 & $517(10 \%)$ & 1,300 & $88(7 \%)$ & $605(10 \%)$ \\
\hline
\end{tabular}


Table 3. Use of nearest airport by local authority area

\begin{tabular}{llll}
\hline Local authority & Nearest airport & $\begin{array}{l}\text { Has used } \\
\text { airport }\end{array}$ & $\begin{array}{l}\text { Has used airport } \\
\text { in the last 12 } \\
\text { months }\end{array}$ \\
\hline North East Derbyshire & East Midlands Airport & $103(87 \%)$ & $49(44 \%)$ \\
Newark and Sherwood & East Midlands Airport & $112(94 \%)$ & $60(50 \%)$ \\
Nottingham & East Midlands Airport & $113(97 \%)$ & $70(60 \%)$ \\
$\begin{array}{l}\text { Hinckley and } \\
\text { Bosworth }\end{array}$ & $\begin{array}{l}\text { Birmingham } \\
\text { International Airport }\end{array}$ & $105(90 \%)$ & $66(56 \%)$ \\
Northampton & Luton Airport & $82(85 \%)$ & $28(30 \%)$ \\
\hline
\end{tabular}


Table 4. Passenger numbers and route provision from the United Kingdom to eight

European, low cost airline destinations, 2007

\begin{tabular}{lllllll}
\hline Destination & \multicolumn{2}{l}{ Passengers } & & \multicolumn{2}{c}{ Routes through (2007) } \\
\cline { 2 - 6 } & $\begin{array}{l}\text { All 2007 } \\
\text { (000’s) }\end{array}$ & $\begin{array}{l}\text { Percentage } \\
\text { change from } \\
2006\end{array}$ & $\begin{array}{l}\text { London } \\
\text { share 2007 }\end{array}$ & $\begin{array}{l}\text { Proportion } \\
\text { charter }\end{array}$ & $\begin{array}{l}\text { London } \\
\text { airports }\end{array}$ & $\begin{array}{l}\text { Regional } \\
\text { airports }\end{array}$ \\
\hline Edinburgh $^{\mathrm{a}}$ & 4,672 & -4.06 & $73.12 \%$ & $0.12 \%$ & 5 & 10 \\
Dublin & 8,587 & $0.64 \%$ & $50.67 \%$ & $0.17 \%$ & 5 & 25 \\
Berlin & 1,576 & $1.49 \%$ & $71.61 \%$ & $0.12 \%$ & $9^{\mathrm{b}}$ & $12^{\mathrm{b}}$ \\
Rome & 2,746 & $5.81 \%$ & $73.06 \%$ & $0.94 \%$ & $8^{\mathrm{b}}$ & $19^{\mathrm{b}}$ \\
Prague & 1,951 & $-4.54 \%$ & $49.59 \%$ & $0.25 \%$ & 4 & 17 \\
Alicante & 4,542 & $-0.15 \%$ & $29.32 \%$ & $23.55 \%$ & 4 & 23 \\
Malaga & 5,055 & $-0.43 \%$ & $37.40 \%$ & $15.55 \%$ & 4 & 22 \\
Faro & 3,216 & $8.52 \%$ & $37.23 \%$ & $27.32 \%$ & 4 & 22 \\
\hline
\end{tabular}

Source: Civil Aviation Authority, 2007

${ }^{a}$ Routes into Edinburgh only, to compare with other destinations

${ }^{\mathrm{b}}$ Services from the same United Kingdom airport to more than one destination airport 
Table 5. Summary of tourism destination preference segment characteristics

\begin{tabular}{llll}
\hline & $\begin{array}{l}\text { Air travel } \\
\text { population segment }\end{array}$ & $\begin{array}{l}\text { Preferred holiday group } \\
\text { size }\end{array}$ & Propensity to Fly \\
\hline $\begin{array}{l}\text { Summer } \\
\text { sun } \\
\text { destination a week }\end{array}$ & $\begin{array}{l}\text { Favoured by } \\
\text { 'retired frequent } \\
\text { flyers' }\end{array}$ & $\begin{array}{l}\text { Most popular for groups of } \\
\text { three or more people }\end{array}$ & $\begin{array}{l}\text { Greatest proportion } \\
\text { would 'definitely' } \\
\text { book a flight }\end{array}$ \\
$\begin{array}{llll}\text { Rome for a } \\
\text { weekend }\end{array}$ & $\begin{array}{l}\text { Favoured by } \\
\text { 'family orientated, } \\
\text { female holiday } \\
\text { makers' }\end{array}$ & $\begin{array}{l}\text { Slightly more popular for } \\
\text { two people travelling } \\
\text { together }\end{array}$ & $\begin{array}{l}\text { Smallest proportion } \\
\text { would book a flight }\end{array}$ \\
$\begin{array}{llll}\text { Rome for a } \\
\text { week }\end{array}$ & $\begin{array}{l}\text { Favoured by } \\
\text { 'retired annual } \\
\text { holiday makers' }\end{array}$ & $\begin{array}{l}\text { Most popular for two } \\
\text { people travelling together }\end{array}$ & $\begin{array}{l}\text { No distinguishing } \\
\text { features }\end{array}$ \\
$\begin{array}{llll}\text { Prague for } \\
\text { a weekend }\end{array}$ & $\begin{array}{l}\text { Favoured by } \\
\text { 'employed frequent } \\
\text { flyer' }\end{array}$ & $\begin{array}{l}\text { Most popular for two } \\
\text { people travelling together } \\
\text { or groups of four or more } \\
\text { people }\end{array}$ & $\begin{array}{l}\text { Greatest overall } \\
\text { proportion would } \\
\text { book a low cost flight }\end{array}$ \\
\hline
\end{tabular}


Table 6. Responses to price sensitivity statements from the East Midlands survey sample

\begin{tabular}{lllll}
\hline & $\begin{array}{l}\text { Probably fly } \\
\text { more often }\end{array}$ & No change & $\begin{array}{l}\text { Probably fly } \\
\text { less often }\end{array}$ & Total \\
\hline React to fare reduction of $£ 20$ & $133(34 \%)$ & $259(66 \%)$ & 0 & 392 \\
React to fare reduction of $£ 10$ & $76(19 \%)$ & $314(81 \%)$ & 0 & 390 \\
React to fare increase of $£ 10$ & 0 & $356(91 \%)$ & $34(9 \%)$ & 390 \\
React to fare increase of $£ 20$ & 0 & $315(81 \%)$ & $76(19 \%)$ & 391 \\
React to fare increase of $£ 50$ & 0 & $146(37 \%)$ & $244(63 \%)$ & 390 \\
React to fare increase of $£ 100$ & 0 & $108(28 \%)$ & $281(72 \%)$ & 389 \\
\hline \multicolumn{7}{l}{ Note: Individual percentages have been rounded up or down, and so may not equal 100.}
\end{tabular}

